\title{
Congressional Fellow Sees Firsthand the Importance of Scientists in Policymaking
}

I had the honor of serving as the Materials Research Society/Optical Society of America Congressional Science and Engineering Fellow from September 2001 through August 2002, and I am very grateful to MRS for allowing me to extend my fellowship to work on several important bills that were still under consideration when my term ended. I worked in the office of Rep. Mike Honda (D-Calif.). I was succeeded by 2002-2003 Fellow Jeff Haeni, who is working in the office of Rep. Rush Holt (D-N.J.), and I recently participated in the selection process for the 2003-2004 Fellow.

Many Americans probably regard the time period that I spent as a fellow as one of the most amazing in recent history. I feel incredibly privileged to have been able to spend that time in Washington D.C., at the center of all the activity, although I will admit that there were days when I questioned whether Washington D.C. was the safest place to be living. It was especially heartening as a scientist to see, even in a time of national crisis, that our government leaders recognize the contributions science and technology can make toward meeting national challenges.

For example, on my first day of work, I reviewed ideas that Rep. Honda was going to propose to the Democratic Homeland Security Task Force for using technology to increase homeland security while preserving civil rights. As the year progressed, homeland security remained an important part of the national agenda and my job. I worked on two amendments that Rep. Honda offered to the Department of Homeland Security bill, one that created a Homeland Security Institute to oversee research and development (R\&D) in the department and another that established a technology clearinghouse to facilitate the application of existing technologies to homeland security problems. Both of these provisions were part of the final bill signed by President George W. Bush.

One of the most memorable moments of my year was the day I accompanied Rep. Honda to the floor of the House of Representatives as he delivered a floor statement I had worked on supporting the National Science Foundation (NSF) doubling bill. The bill, which would allow Congress to increase the amount of money it provides to the NSF, has been a priority of MRS and other professional societies in the physical science community. It would

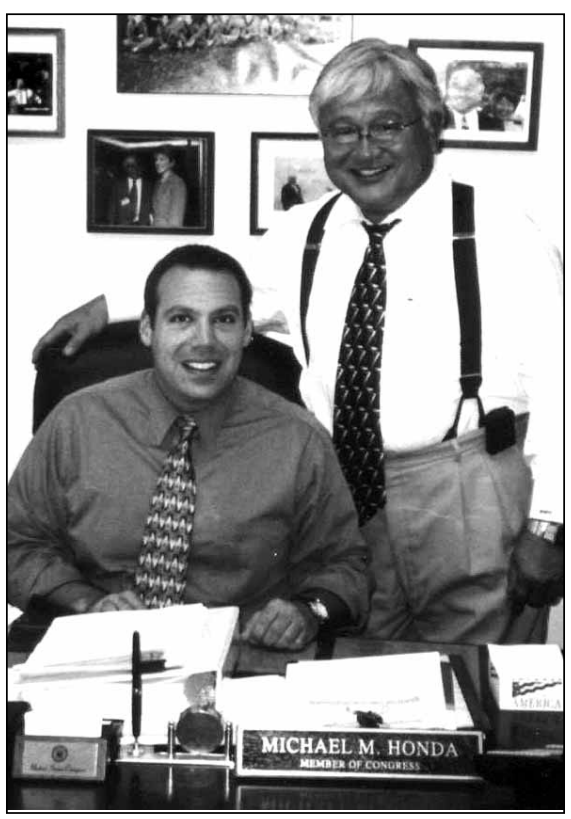

Congressional Fellow Eric Werwa (left) worked for Rep. Mike Honda (D-Calif.) (right) from September 2001 through August 2002.

enable increased funding each year, so that after five years, Congress could spend twice the current funding level on NSF. The bill received overwhelming support in the House of Representatives, and a similar version was ultimately approved in the U.S. Senate. After some tense moments at the end of last fall's congressional session, when we wondered if a deal would be reached, the two houses were able to work out the differences between their bills. On the last night of the session a bill was approved and sent to the president, who signed it into law.

\begin{tabular}{c} 
"One of the most \\
memorable moments of \\
my year was the day I \\
accompanied Rep. Honda \\
to the floor of the House \\
of Representatives." \\
\hline
\end{tabular}

This bill illustrates one of the major concepts that I learned during my fellowship: the difference between authorization and appropriation of funds. The NSF doubling bill is an authorizing bill, meaning that it establishes a maximum amount that Congress is allowed to spend on NSF. It provides no guarantee of that amount, however. In fact, when President Bush submitted his budget request for fiscal year 2004, the actual funding level for NSF was well below the level authorized by the NSF doubling bill he had signed into law just two months before.

The budget request serves only as a recommendation to the Congress about how the administration feels funding should be divided among federal agencies, however. The Appropriations Committees in the House and Senate prepare bills specifying how much money should be provided to each agency. The Department of Veterans Affairs, the Department of Housing and Urban Development, and Related Agencies Subcommittees are responsible for determining the amount that will be provided to NSF in fiscal year 2004, and congressional supporters of NSF will communicate to their colleagues on these committees that the level of funding should exceed the amount requested by the president.

This process, which is just now beginning, provides individual scientists with the opportunity to have their voices heard about the importance of science funding. By contacting our senators and representatives and stressing to them the importance of federal funding for basic research to the country, we may be able to convince them to join the ranks of congressional supporters of NSF who are lobbying their colleagues to increase NSF's appropriation. Increasing the NSF authorization level required a lot of work by MRS and other societies, but the fight is not over, and MRS members need to be heard in order to achieve the ultimate goal of seeing real increases in NSF funding.

These two bills are just a small part of what I worked on during my fellowship year. I was one of more than 30 science and technology policy fellows working in Congress, and there were approximately 60 others working within federal agencies around Washington D.C., which demonstrates the impact that these scientists working temporarily within government can actually have. At the end of my fellowship year I found that I was enjoying science policy so much and had made myself so useful to my office that I have remained in Rep. Honda's office as a permanent staff member.

ERIC WERWA 